\title{
Analysis Of Character Education Implementation Through 5 Habits (Smile, Handshake, Greeting, Politeness, And Courtesy) in SD Negeri 1 Kutosari, Kebumen Sub-District, Kebumen Regency
}

\author{
Khimatun Nafilah, Tri Saptuti Susiani, Muhamad Chamdani \\ Universitas Sebelas Maret \\ naphilbabeh@gmail.com
}

\author{
Article History \\ accepted 01/06/2020x
}

approved 01/07/2020

published 01/08/2020

\begin{abstract}
Character education is very important for student, because the purpose of character education is to understand students' values and update their living arrangements. The objectives of the research were to describe: (1) the implementation of character education through 5 habits, (2) to describe the implication of character values about 5 habits, (3) to analyze the obstacles and solutions in implementing 5 habits. The research used descriptive qualitative research. The results showed that the implementation of 5 habits and the implementation of character values at school run well while the obstacle was the students failed to implement 5 habits at home. It affected the implementation of 5 habits at school. The solution was the teachers supervised and managed the students to implement 5 habits consistently in daily life. It concludes that the implementation of character education through 5 habits run very well with cumulative presentation $96,2 \%$ and the obstacle was handled by the teachers.
\end{abstract}

Keywords: Analysis, Character education, 5 habits

\begin{abstract}
Abstrak
Pendidikan karakter sangat penting untuk peserta didik, karena tujuan pendidikan karakter adalah pemahaman nilai dalam diri siswa dan pembaruan tata kehidupan bersama. Tujuan penelitian ini yaitu mendeskripsikan: (1) pelaksanaan implementasi pendidikan karakter melalui budaya 5S; (2) implikasi nilai karakter dalam budaya; (3) hambatan dan solusinya dalam pelaksanaan budaya 5S. Penelitian ini menggunakan metode penelitian kualitatif tipe deskriptif. Hasil penelitian menunjukkan bahwa: pelaksanaan budaya 5S (senyum, salam, sapa, sopan, dan santun) tergolong sangat baik, implikasi nilai karakter di lingkungan sekolah terlihat baik, hambatan dalam pelaksanaan $5 S$ yaitu kebiasaan peserta didik di rumah yang belum menerapkan budaya $5 S$ sehingga mempengaruhi pelaksanaan saat di sekolah dan upaya yang dilakukan guru yaitu melakukan pengawasan dan pendampingan peserta didik secara konsisten dalam penerapannya. Kesimpulan penelitian ini adalah implementasi pendidikan karakter melalui budaya 5 S dengan kumulatif persentase pelaksanaan $96,2 \%$ tergolong sangat baik dan hambatan dalam pelaksanaan telah diatasi oleh guru.
\end{abstract}

Kata kunci: analisis, Pendidikan karakter, Budaya 5S 


\section{PENDAHULUAN}

Pendidikan merupakan usaha sadar yang dilakukan untuk membentuk sebuah kepribadian manusia dalam segala hal yang menyangkut keagamaan, pengendalian diri, akhlak mulia serta keterampilan. Pendidikan dilakukan oleh pendidik ke peserta didik untuk mengubah tingkah laku peserta didik menjadi lebih baik dan lebih berakhlak mulia. Pendidikan juga akan berdampak pada karakter yang dimiliki oleh peserta didik, dimana karakter itu dapat dilihat dan diamati melalui sikap dan perilaku yang dimiliki oleh peserta didik sehingga pendidikan harus dapat membuat peserta didik memiliki karakter baik.

Tujuan pendidikan di Indonesia tertera pada Undang-undang Sistem Pendidikan Nasional 2013 UU RI No. 20 Tahun 2003 Bab II Pasal 3 yang berbunyi :

Pendidikan nasional berfungsi mengembangkan kemampuan dan membentuk watak serta peradaban bangsa yang bermartabat dalam rangkamencerdaskan kehidupan bangsa, bertujuan untuk berkembangnya potensi peserta didik agar menjadi manusia beriman dan bertakwa kepada Tuhan Yang Maha Esa, berakhlak mulia, sehat, berilmu, cakap, kreatif, mandiri, dan menjadi warga negara yang demokratis serta bertanggung jawab.

Dalam mencapai tujuan pendidikan di Indonesia yang diharapkan memerlukan suatu proses. Proses yang dilakukan untuk mencapai tujuan tersebut masih memiliki beberapa hambatan sehingga tujuan pendidikan di Indonesia yang sudah ada dalam Undang-Undang Sistem Pendidikan Nasional 2013 UU RI No. 20 Tahun 2003 belum bisa terlaksana secara optimal

Berdasarkan pengamatan, merosotnya moral peserta didik ditandai dengan melunturnya rasa malu yang dimiliki oleh peserta didik. Peserta didik kini banyak yang terang-terangan menggunakan rokok, minuman keras bahkan sampai pada penggunaan narkoba. Selain itu, yang mengkhawatirkan lagi tingkah laku yang dimiliki oleh peserta didik. Beberapa peserta didik didapati menggunakan kata kasar dalam keseharian, memanggil teman dengan sebutan yang tidak pantas, bahkan mencaci fisik dari gurunya. Dari beberapa masalah yang ada, peneliti melakukan pengamatan dan diskusi untuk mencari solusi.

Guru sebagai pendidik merupakan salah satu pembentuk karakter peserta didik supaya lebih baik lagi. Guru memiliki peran untuk mengubah moral generasi penerus bangsa menjadi lebih baik pada lingkungan sekolah maupun lingkungan sosial. Dalam hal ini pemerintah juga ikut berpartisipasi dalam menanamkan pendidikan karakter dengan tujuan memperbaiki moral generasi penerus bangsa. Pendidikan karakter yang diharapkan mampu menanamkan kebiasaan baik sehingga peserta didik dapat merasakan manfaat kebaikan dan menjadikan kebaikannya sebagai kebiasaan. Asmani (2013) mengatakan bahwa tujuan pendidikan karakter adalah pemahaman nilai dalam diri siswa dan pembaruan tata kehidupan bersama yang lebih menghargai kebebasan individu.

Dari uraian tersebut dapat disimpulkan bahwa pendidikan karakter sangat penting untuk peserta didik. Peneliti tertarik untuk melakukan penelitian mengenai Implementasi Pendidikan Karakter melalui Budaya 5S di SD Negeri 1 Kutosari, karena berdasarkan pengamatan, peneliti mengetahui bahwa di SD Negeri 1 Kutosari menerapkan Budaya 5S (Senyum, salam, sapa, sopan, dan santun) sebagai usaha 
untuk menanamkan pendidikan karakter. Pratiwi (2017) menyatakan bahwa Budaya 5S merupakan suatu anjuran yang dilakukan oleh seseorang ketika berkomunikasi dan bersosialisasi kepada orang lain.

Budaya 5S adalah suatu program yang dilakukan sebagai upaya dalam menanamkan pendidikan karakter. Budaya 5S mencakup nilai karakter yaitu: (1) religius, (2) Rasa toleransi, (3) Bersahabat/komunikatif, (4) Cinta damai, (5) Peduli Sosial. Pendidikan karakter melalui Budaya 5S (senyum, salam, sapa, sopan, dan santun) dilakukan dengan 4 cara, yaitu: (1) kegiatan rutin, (2) kegiatan spontan, (3) keteladanan, dan (4) pengkondisian.

Rumusan masalah dari penelitian ini yaitu: (1) Bagaimana implementasi pendidikan karakter melalui budaya $5 S$ di SD Negeri 1 Kutosari Kecamatan Kebumen Kabupaten Kebumen ?; (2) Bagaimana implikasi nilai karakter dalam budaya 5S di SD Negeri 1 Kutosari Kecamatan Kebumen Kabupaten Kebumen?; (3) Bagaimana hambatan dan solusi dari pelaksanaan pendidikan karakter melalui budaya $5 S$ di SD Negeri 1 Kutosari Kecamatan Kebumen Kabupaten Kebumen?

Tujuan penelitian ini yaitu: (1) mendeskripsikan pelaksanaan implementasi pendidikan karakter melalui budaya $5 S$ di SD Negeri 1 Kutosari; (2) mendeskripsikan implikasi nilai karakter dalam budaya 5S di SD Negeri 1 Kutosari; (3) menganalisis hambatan dan solusinya dalam pelaksanaan budaya 5S di SD Negeri 1 Kutosari.

\section{METODE}

Penelitian dilaksanakan di SD Negeri 1 Kutosari, Kecamatan Kebumen, Kabupaten Kebumen. Subjek penelitian ini adalah peserta didik kelas III,IV, dan V. Sumber data yang digunakan meliputi kepala sekolah, guru, dan peserta didik. Penelitian dilaksanakan dari bulan November tahun 2019 sampai bulan Maret tahun 2020.

Penelitian ini menggunakan metode penelitian kualitatif tipe deskriptif. Sumber data yang digunakan meliputi kepala sekolah, guru, dan peserta didik. Data yang digunakan berupa data kualitatif hasil deskripsi peneliti mengenai analisis pelaksanaan implementasi pendidikan karakter melalui budaya 5S (senyum, salam, sapa, sopan, dan santun), hambatan, serta upaya untuk menangani hambatannya. Teknik pengumpulan data yang digunakan dalam penelitian ini meliputi hasil observasi, wawancara, dan angket kualitatif. Teknik uji validitas data pada penelitian ini adalah teknik triangulasi sumber. Teknik analisis data pada penelitian ini melalui reduksi data, penyajian data, dan verifikasi. Proses analisis data pada penelitian kualitatif ini mengacu pada model analisis data menurut Miles dan Huberman (Sugiyono, 2016) yang terdiri dari reduksi data, penyajian data, dan verifikasi

\section{HASIL DAN PEMBAHASAN}

Penelitian kualitatif deskriptif yang dilakukan terdiri dari 15 kali observasi, wawancara dengan 3 narasumber berbeda, dan angket kualitatif untuk mendapatkan data yang stabil. Budaya 5S di SD Negeri 1 Kutosari merupakan budaya sekolah yang dikembangkan sesuai dengan penuturan Kepala Sekolah, beberapa rekan guru dan beberapa peserta didik. Budaya 5S dilaksanakan melalui kegiatan rutin, kegiatan spontan, keteladanan dan pengkondisian, bersumber pada pendapat Gunawan (2012) dan pendapat Muslich (2015). Kegiatan rutin dilakukan sebagai upaya penanaman pendidikan karakter karena dengan pembiasaan akan menimnulkan karakter yang menjadi ciri khas suatu individu. Menurut Shoimah (2018) penanaman karakter harus 
dibiasakan diamalkan secara berulang-ulang agar menjadi kebiasaan dan terbentuk karakter yang sesuai dengan yang diinginkan. Penanaman pendidikan karakter juga dapat dilaksanakan melalui keteladanan guru. Menurut Suwandi dalam Nurchaili (2010) pelaksanaan pendidikan karakter di sekolah lebih tepat melalui pendekatan modelling atau keteladanan yang dilakukan oleh guru. Hal tersebut dikarenakan karakter merupakan perilaku bukan pengetahuan. Selain itu, penanaman karakter juga didukung dengan suatu pengkondisian. Pengkondisian disini berarti pengkondisian lingkungan dengan maksud pelaksanaan budaya 5S didukung oleh lingkungan yang nyaman di sekolah. hal ini sejalan dengan penelitian Murpratiwi (2013: 11) yang menyatakan bahwa pengkondisian lingkungan dinilai cukup efektif diterapkan dalam membiasakan nilai-nilai karakter terutama yang sifatnya anjuran.

Penanaman pendidikan karakter melalui budaya $5 \mathrm{~S}$ sudah terlaksana dengan sangat baik oleh peserta didik, guru, maupun tenaga kependidikan lainnya. Hal tersebut dilihat dari aspek pelaksanaan budaya 5S (senyum, salam, sapa, sopan, dan santun) di SD Negeri 1 Kutosari yang terdiri dari kegiatan rutin, kegiatan spontan, keteladanan, dan pengkondisian mencapai keberhasilan yang sangat baik. Dari indikator pelaksanaannya hanya terdapat satu indikator yang tidak mencapai keberhasilan 100\%. Indikator lain terlaksana dengan sangat baik dan konsisten. Berdasarkan Kemendiknas (2010) perencanaan pendidikan budaya dan karakter bangsa dapat dilaksanakan dalam program pengembangan diri, dalam mata pelajaran dan budaya sekolah. Dalam penelitian ini SD Negeri 1 Kutosari melaksanakan penanaman karakter melalui budaya sekolah yaitu budaya 5S. Dapat diketahui bahwa keberhasilan pelaksanaan budaya 5S (Senyum, sapa, salam, sopan, dan santun) sesuai dengan indikator pelaksanaan sudah berjalan dengan sangat baik. Jika dihitung dari rata-rata, pelaksanaannya sudah mencapai hampir $100 \%$ terlaksana. Indikator tersebut terbagi atas kegiatan rutin, kegiatan spontan,keteladanan, dan pengkondisian.

Tabel 1 Keberhasilan Pelaksanaan Budaya 5S (Senyum, salam, sapa, sopan, dan santun) peserta didik kelas III, IV, dan V SD Negeri 1 Kutosari

\begin{tabular}{|c|c|c|}
\hline $\begin{array}{l}\text { Aspek yang } \\
\text { diamati }\end{array}$ & Indikator & Keterangan \\
\hline \multirow[t]{4}{*}{$\begin{array}{l}\text { 1. Kegiatan } \\
\text { rutin }\end{array}$} & $\begin{array}{l}\text { a) Murah senyum kepada teman dan guru } \\
\text { kelas. }\end{array}$ & Terlaksana \\
\hline & $\begin{array}{l}\text { b) Kegiatan salaman dengan guru sebelum } \\
\text { masuk kelas dan hendak pulang ke } \\
\text { rumah. }\end{array}$ & Terlaksana \\
\hline & c) Menggunakan kalimat sapaan yang sopan & $\begin{array}{l}\text { NBL } \\
\text { menyimpang } \\
\text { pada } \\
\text { tanggal28 } \\
\text { Januari } 2020\end{array}$ \\
\hline & $\begin{array}{l}\text { d) Menggunakan bahasa yang baik saat } \\
\text { berbisara dengan teman dan guru di } \\
\text { sekolah. }\end{array}$ & Terlaksana \\
\hline
\end{tabular}

2. Kegiatan spontan a) Ramah dan senyum ketika bertemu warga Terlaksana sekolah di luar kelas. 


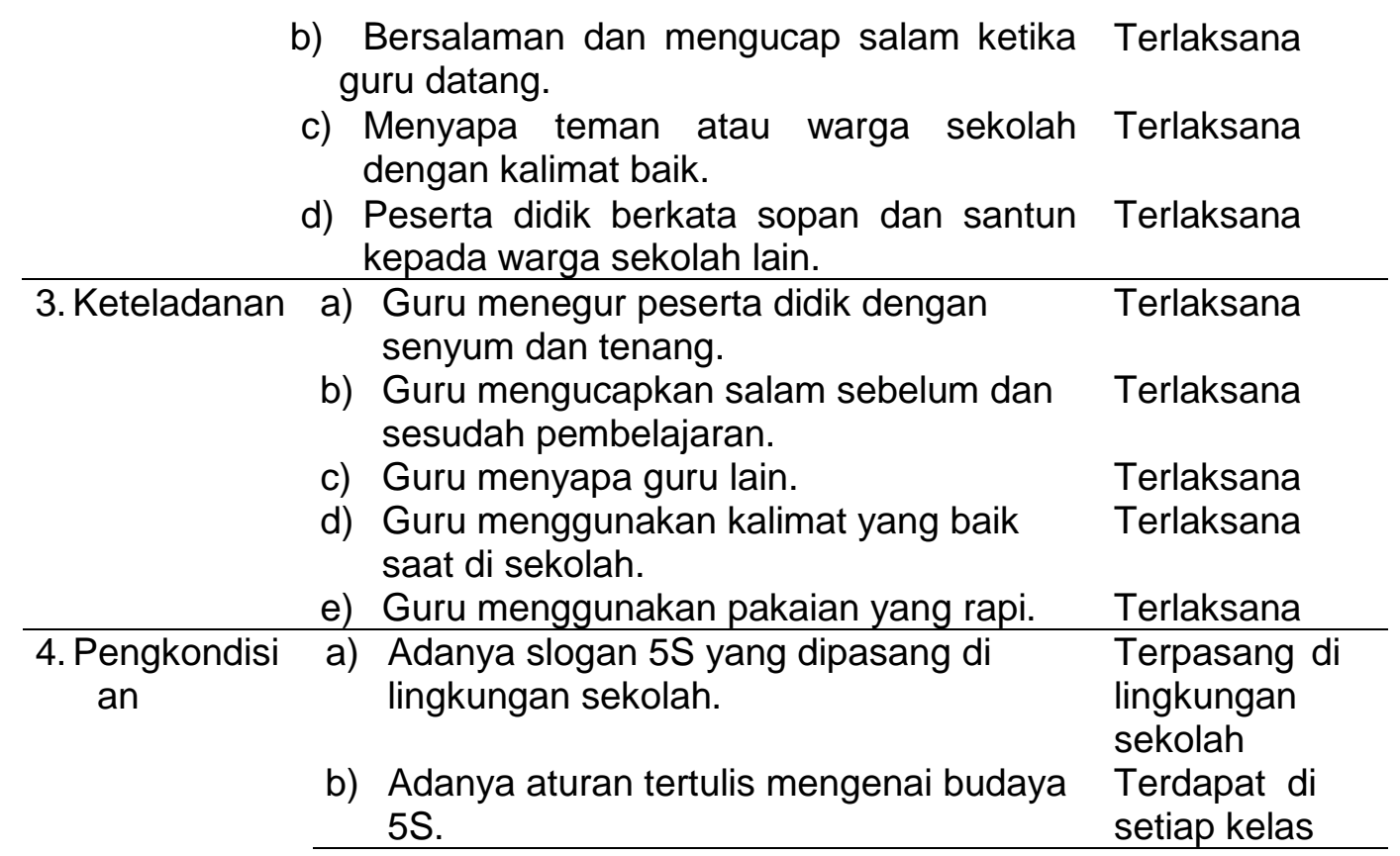

Berdasarkan tabel di atas, dapat diketahui bahwa dari segi pelaksanaan pendidikan karakter pada peserta didik sudah sangat baik. Dari indikator kegiatan rutin terdapat satu peserta didik yang didapati peneliti menggunakan kalimat sapaan yang kurang sopan. Peserta didik tersebut berinisial NBL yang duduk di kelas II. Menurut guru kelas, peserta didik tersebut memang masih sering didapati meledek temannya dengan panggilan selain nama temannya dengan tujuan bermain. Selain pelaksanaan indikator kegiatan rutin dan kegiatan spontan, terdapat dua indikator lain yaitu keteladanan dan pengkondisian. Pada indikator keteladanan dan pengkondisian semua aspek terpenuhi $100 \%$.

Tujuan implementasi pendidikan karakter melalui budaya 5S (Senyum, sapa, salam, sopan, dan santun) adalah untuk melatih peserta didik memiliki karakter religius, toleransi, komunikatif, cinta damai, dan peduli sosial sehingga peserta didik dapat menerapkannya dalam kehidupan berupa: bersikap ramah tamah, mengucapkan salam, menyapa orang lain dengan kalimat baik, berkata sopan, dan yang paling penting yaitu menghargai orang lain. Senyum, sapa, dan salam merupakan hal yang kecil tetapi memiliki makna yang besar dan jika tidak dicoba untuk dilakukan dan berusaha menjadikan itu sebagai budaya maka sangat sulit melakukannya. Hal tersebut selaras dengan pendapat Nurhasan (2015) menjelaskan bahwa sapaan merupakan bentuk komunikasi awal kita dengan orang lain. Implikasi nilai karakter budaya $5 S$ (senyum, salam, sapa, sopan, dan santun) sudah dapat terlaksana dengan sangat baik oleh mayoritas peserta didik yang dijadikan sampel dalam penelitian. Nilai karakter tersebut meliputi religius sebesar 100\%, toleransi sebesar $96 \%$, komunikatif/bersahabat sebesar 97\%, cinta damai sebesar $93 \%$, dan peduli sosial mencapai persentase sebesar 95\%. Indikator yang mewakili masing-masing nilai karakter terlaksana dengan sangat baik di sekolah, data tersebut didapat dari hasil observasi, wawancara guru dan kepala sekolah,serta angket kualitatif yang diberikan kepada peserta didik. Dalam hal ini penanaman nilai karakter, Cahyaningrum (2017) 
berpendapat bahwa penting dilakukan penanaman nilai karakter pada anak untuk memaksimalkan kemampuan dan potensi yang dimiliki anak.

Namun, terlepas dari hasil penelitian yang sudah baik, ditemukan hambatan dalam pelaksanaan budaya 5S. Hambatan diketahui peneliti melalui proses wawancara guru dan kepala sekolah, serta observasi dari peneliti. Hasil wawancara dari tiga guru dan kepala sekolah menyebutkan bahwa hambatan terletak pada kebiasaan peserta didik di rumah yang belum menerapkan budaya $5 \mathrm{~S}$ sehingga mempengaruhi pelaksanaan saat di sekolah. Keseriusan dalam pelaksanaan budaya $5 S$ menjadi salah satu hambatan. Hal ini juga ditemukan oleh peneliti saat melakukan observasi. Peneliti menemukan beberapa peserta didik yang kelupaan tidak mengucapkan salam saat bertemu guru piket di depan gerbang sekolah, tetapi hal tersebut diingatkan oleh guru untuk mengucap salam ketika bertemu teman dan guru di sekolah serta mengucap salam ketika keluar masuk rumah. Mengenai hambatan yang disebutkan sependapat dengan Burhaein yang menyatakan bahwa peserta didik sekolah dasar masih belum bisa memikirkan keseriusan dan masih senang bermain. (2017), oleh sebab itu yang dilakukan guru sebagai solusi dari hambatan yaitu melakukan pengawasan dan pendampingan supaya peserta didik secara konsisten menerapkannya dalam kehidupan sehari-hari.

\section{SIMPULAN}

Penanaman pendidikan karakter melalui budaya 5S sudah terlaksana dengan sangat baik oleh peserta didik, guru, maupun tenaga kependidikan lainnya. Hal tersebut dilihat dari aspek pelaksanaan budaya $5 S$ (senyum, salam, sapa, sopan, dan santun) yang terdiri sari kegiatan rutin, kegiatan spontan, keteladanan, dan pengkondisian mencapai keberhasilan yang sangat baik. Dari indikator pelaksanaannya hanya terdapat satu indikator yang tidak mencapai keberhasilan $100 \%$. Indikator lain terlaksana dengan sangat baik dan konsisten.

Implikasi nilai karakter budaya $5 \mathrm{~S}$ (senyum, salam, sapa, sopan, dan santun) sudah dapat terlaksana dengan sangat baik oleh mayoritas peserta didik yang dijadikan sampel dalam penelitian. Indikator yang mewakili masing-masing nilai karakter terlaksana dengan sangat baik di sekolah.

Hambatan dalam pelaksanaan budaya 5S terletak pada kebiasaan peserta didik di rumah yang belum menerapkan budaya $5 S$ sehingga mempengaruhi pelaksanaan saat di sekolah. Data tersebut diperoleh dari hasil wawancara guru, kepala sekolah dan hasil observasi peneliti. Upaya yang dilakukan guru sebagai solusi dari hambatan yaitu guru melakukan pengawasan dan pendampingan kepada peserta didik.

Berkaitan dengan hasil penelitian yang telah dicapai, peneliti mengajukan rekomendasi sebagai berikut: (1) Guru sebaiknya tetap memberikan pengawasan dan pendampingan lebih baik lagi kepada peserta didik ketika di sekolah khususnya ketika istirahat sehingga peserta didik benar-benar menerapkan nilai karakter dari budaya $5 S$ dengan baik; (2) Sekolah hendaknya selalu konsisten dalam menerapkan budaya $5 S$ sehingga penanaman nilai karakter didalamnya dapat terlaksana secara berkelanjutan; (3) Peserta didik sebaiknya membudayakan senyum, salam, sapa, sopan, dan santun sebagai baik di rumah maupun di sekolah, walaupun memiliki kondisi lingkungan yang berbeda tetapi dapat merasakan atmosfer yang sama sehingga menyebabkan suasana belajar yang harmonis dan sejahtera; dan 4 peneliti lain diharapkan meneliti 
lebih lanjut secara mendalam pula mengenai budaya $5 S$ khususnya dalam segi hambatan pelaksanaan, sehingga peneliti selanjutnya dapat menginovasi upaya yang dilakukan dalam penanganan hambatan dalam pelaksana budaya $5 \mathrm{~S}$ (senyum, salam, sapa, sopan, dan santun).

\section{DAFTAR PUSTAKA}

Asmani, J.M. (2013). Buku Panduan Internalisasi Pendidikan Karakter di Sekolah. Yogyakarta: DIVA Press.

Burhaein, E. (2017). Aktivitas Fisik Olahraga untuk Pertumbuhan dan Perkembangan Siswa SD. Indonesian Journal of Primary Education, 1(1), 52-53. Diperoleh pada 11 Maret 2020, dari: http://ejournal.upi.edu/index.php/lJPE/index.

Cahyaningrum, E.S. (2017). Pengembangan nilai karakter anak melalui pembiasaan dan keteladanan. Diperoleh pada 12 April 2020, dari: https://journal.uny.ac.id/index.php/jpa/article.17707/10181.pdf.

Gunawan, H. (2012). Pendidikan karakter Konsep dan Implementasi. Bandung: Alfabeta.

Kemendiknas. (2010). Pengembangan Pendidikan Budaya dan Karakter Bangsa Pedoman Sekolah. Diakses dari http://gurupembaharu.com/beta2/wpcontent/plugins/download-monitor/download.php?id=2920. Hari minggu, tanggal 3 november 2019 jam 4:52.

Nurchaili. (2010). Membentuk Karakter Siswa Melalui Keteladanan Guru. Jurnal Pendidikan dan Kebudayaan. Vol. 16, Edisi Khusus III. Diperoleh dari https://jurnaldikbud.kemdikbud.go.id/index.php/jpnk/article/download/515/35 4, pada tanggal 20 Mei 2020.

Nurhasan. (2015). Penerapan Senyum Pustakawan sebagai Keterampilan Sosial dan Pustakawan. Jurnal Volume IX nomor 2. Diunduh tanggal 12 April 2020, dari https://jurnal .ugm.ac.id/bip/article/download/10032/7543.

Murpratiwi,K. (2013). Pelaksanaan Pendidikan Karakter Melalui Pengkondisian Lingkungan Sekolah di SMK PGRI Kota Malang. Diperoleh melalui https://journal.uny.ac.id/index.php/jpka/article/viewFile/1287/1071, $\quad$ pada tanggal 21 Mei 2020.

Muslich, M. (2011). Pendidikan Karakter Menjawab Tantangan Krisis Multidimensional. Jakarta: Bumi Aksara.

Pratiwi, I. S. (2017). Pembiasaan Budaya 5S untuk Menumbuhkan Nilai Karakter dan

Budi Pekerti Siswa. Prosiding Seminar Nasional Universitas Muria Kudus. Diunduh pada tanggal 4 November 2019.

Shoimah. (2018). Pendidikan Karakter melalui Pembiasaan di Sekolah Dasar. JKTP Vol. 1, nomor 2, Juni 2018. Diperoleh melalui http://journal2.um.ac.id/index.php/jktp/article/download/4206/277, $\quad$ pada tanggal 20 Mei 2020. 
Volume 8 Nomor 2 Tahun 2020

Sugiyono. (2016). Metode Penelitian Kuantitatif, Kualitatif, R\&D. Bandung: Alfabeta.

Undang-Undang SISDIKNAS (Sistem Pendidikan Nasional) (UU RI No.20 Th.2003). Jakarta: Sinar Grafika. 